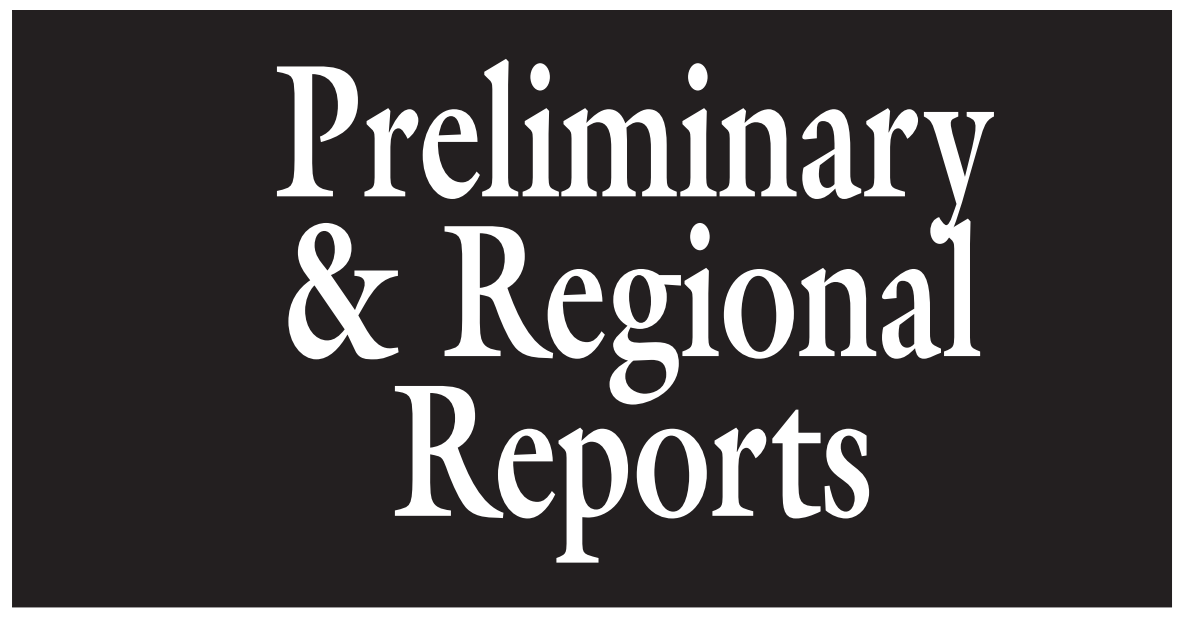

\title{
Northern Field Production of Leaf and Romaine Lettuce using a High Tunnel
}

\author{
Heidi B. Rader and Meriam G. Karlsson
}

\begin{abstract}
Additional Index words. Lactuca sativa, 'Two Star', 'Parris Island Cos', plasticulture, hoop house, season extension

Summary. A high tunnel environment was evaluated for production of leaf ('Two Star') and romaine ('Parris Island Cos') lettuce (Lactuca sativa) in a northern location (lat. $64^{\circ} 49^{\prime} \mathrm{N}$ ). Ten plantings were made 1 week apart from May to August. Averaged over the season, the air temperature was $1.5^{\circ} \mathrm{C}$ and the soil $0.8^{\circ} \mathrm{C}$ higher in the high tunnel than the field. 'Two Star' planted on $3 \mathrm{Aug}$. and harvested on 16 Sept. produced higher yield $(P<0.001)$ in the tunnel. Head weight was $195 \pm 12 \mathrm{~g}$ in the tunnel and $99 \pm 8 \mathrm{~g}$ in the field. For the 13 Julyplanted 'Two Star' lettuce, the field produced significantly $(P<0.001)$ more at $202 \pm 21 \mathrm{~g} / \mathrm{head}$ than the $135 \pm 29 \mathrm{~g} / \mathrm{head}$ in the tunnel. The three consecutive field plantings of 1,8 , and 15 June resulted in higher 'Parris Island Cos' yields than corresponding plantings in the high tunnel. Head weights for harvests on 11,18 , and 25 July were $457 \pm 60,476 \pm 65$, and $478 \pm 25 \mathrm{~g}$ under field conditions and $354 \pm 46,331 \pm 52$, and $312 \pm 14 \mathrm{~g}$ in the high tunnel. 'Two Star' was observed less prone to bolting than 'Parris Island Cos'. Although a high tunnel did not generally support increased productivity in this study, the added protection resulted in high quality lettuce with limited necessary preparation and marketing loss in comparison to the field-grown lettuce.
\end{abstract}

$\mathrm{H}$ igh tunnels are temporary field greenhouses that use solar heat to more rapidly increase air and soil temperatures than an open field (Lamont et al., 2003; Wells and Loy, 1993). These structures are manually ventilated and usually irrigated with drip tape, emitters, or soaker hoses. In general, high tunnels improve yield and crop quality through improved temperatures, lower disease and pest incidence (Waterer, 2003), and protec-

SNRAS/AFES Publication Number 2006-006

Department of Plant, Animal and Soil Sciences, University of Alaska, Fairbanks, AK 99775-7200. tion from rain, wind, and hail (Hodges and Brandle, 1996). For instance, high tunnels used for late winter strawberry (Fragaria $\times$ ananassa) production in Kansas improved earliness, yield, and fruit quality and protected the plants from low winter temperatures (Kadir et al., 2006). Although high tunnel field production is used less often in North America compared with Europe, a range of crops are now successfully produced in various regions of the U.S. and Canada. Reasons for lower use in the U.S. could be due to lower transportation costs, cheaper food, highly centralized marketing systems, and consumer reluctance to pay for high quality, fresh, local produce (Hancock and Simpson, 1995). In areas with field seasons of moderate temperatures and limited duration, high tunnels may serve well to improve and extend crop productivity over the season.

Cos or romaine lettuce has long, narrow leaves that form oval-shaped heads (Ryder, 1979) while leaf lettuce is characterized by soft, open heads that are more easily damaged during shipment. California produces about $81 \%$ of U.S. leaflettuce, the majority of which is romaine and a smaller percentage, green leaf lettuce (Kurtz, 2001). Generally, lettuce is considered a cool season crop with optimum production temperatures of $23^{\circ} \mathrm{C}$ during the day and $7{ }^{\circ} \mathrm{C}$ at night (Jackson et al., 1996). Lower than optimal temperatures slow growth, and temperatures beyond optimal often result in bolting, bitterness, tipburn, and poor heading. Higher than $32^{\circ} \mathrm{C}$ may also result in thermodormancy.

Modern cultivars of leaf lettuce have been developed to tolerate warmer growing regions and conditions such as greenhouses (Bierhuizen et al., 1973; Wien, 1997). For lettuce to properly form heads, individual leaves need to be sufficiently large, petioles short, rate of stem elongation slow, and the production of leaves adequately fast (Wien, 1997). Bolting, the failure to properly form a head due to excessively rapid stem elongation or leaf twisting (Nothmann, 1977a), may be especially problematic under combinations of elevated temperatures in high tunnels

\begin{tabular}{llll}
\hline $\begin{array}{l}\text { Units } \\
\text { To convert U.S. to SI, } \\
\text { multiply by }\end{array}$ & U.S. unit & SI unit & $\begin{array}{l}\text { To convert SI to U.S., } \\
\text { multiply by }\end{array}$ \\
\hline 0.3048 & $\mathrm{ft}$ & $\mathrm{m}$ & 3.2808 \\
0.0929 & $\mathrm{ft}^{2}$ & $\mathrm{~m}^{2}$ & 10.7639 \\
3.7854 & $\mathrm{gal}$ & $\mathrm{L}$ & 0.2642 \\
2.54 & inch $(\mathrm{es})$ & $\mathrm{cm}$ & 0.3937 \\
1.1209 & $\mathrm{lb} / \mathrm{acre}$ & $\mathrm{kg} \cdot \mathrm{ha}^{-1}$ & 0.8922 \\
0.0254 & $\mathrm{mil}$ & $\mathrm{mm}$ & 39.3701 \\
1 & $\mathrm{mmho} / \mathrm{cm}$ & $\mathrm{dS} \cdot \mathrm{m}^{-1}$ & 1 \\
28.3495 & $\mathrm{oz}$ & $\mathrm{g}$ & 0.0353 \\
$\left({ }^{\circ} \mathrm{F}-32\right) \div 1.8$ & ${ }^{\circ} \mathrm{F}$ & ${ }^{\circ} \mathrm{C}$ & $\left(1.8 \times{ }^{\circ} \mathrm{C}\right)+32$
\end{tabular}


and the naturally extended daylengths of high latitude locations.

Temperature is the most important environmental factor for lettuce growth prior to complete soil coverage (Bierhuizen et al., 1973). Canopy extension was faster under elevated temperatures which led to increased light interception (Challa, 1990; Pearson et al., 1997). Even small temperature enhancements in a high tunnel environment may therefore significantly improve crop productivity. Though faster maturity and growth can be expected under slightly warmer conditions (Boxall, 1971), excessively high temperatures may be counterproductive. Soil temperatures near $36^{\circ} \mathrm{C}$ led to poor heading, leaf twisting, reduced leaf size, decreased head weight, and poor shoot and root development (Nothmann, 1977b). Vegetative head disintegration, a reversal of the rosette stage, was noted with soil temperatures at 28 to $36{ }^{\circ} \mathrm{C}$ (Nothmann, 1977b).

Increasing temperatures, irradiance, and daylengths in the spring slowed growth of romaine lettuce but still resulted in consistent heading with minimal leaf twisting (Nothmann, 1977a) and low bolting tendency (Bierhuizen et al., 1973). High temperature and irradiance in the summer limited leaf folding and produced soft, open heads with frequent bolting (Glenn, 1984; Nothmann, 1997a). In the fall, growth was initially rapid but decreased as temperature, irradiance, and daylength decreased (Nothmann, 1977a). In the cool temperatures of winter, growth was slow with late heading and limited bolting under the gradually increasing daylengths (Nothmann, 1977a).

In Kansas, lettuce grown in high tunnels bolted more quickly, tasted bitter, and had lower nitrate levels (Zhao et al., 2003). Wind speed was reduced although air temperature and relative humidity in the high tunnel were comparable to the open field. Several leaf lettuce cultivars including 'Two Star' were more heat and bolting sensitive when grown in the high tunnel (X. Zhao, personal communication). Overhead sprinkle irrigation and shading reduced bolting, but these practices may negate some of the benefits derived from high tunnel production.

Alaska field conditions differ significantly from those of major lettuce-producing areas in the U.S. The limited growing season of high latitudes requires field establishment through sequential transplanting rather than direct seeding. Regions of California with extensive lettuce production have days of 17 to $28^{\circ} \mathrm{C}$ and nights from 3 to $12^{\circ} \mathrm{C}$ (Jackson et al., 1996). The average temperature during the field season of June, July, and August in Fairbanks, Alaska (lat. $64^{\circ} 49^{\prime} \mathrm{N}$, long. $147^{\circ} 52^{\prime} \mathrm{W}$ ), has been recorded at $15.4^{\circ} \mathrm{C}$ for 1996 through 2005 along with $10.1{ }^{\circ} \mathrm{C}$ minimum and $20.8^{\circ} \mathrm{C}$ maximum averages (Alaska Climate Research Center, 2006). The longest day is $14 \mathrm{~h}$ and $41 \mathrm{~min}$ (U.S. Naval Observatory, 2006) in Salinas, Calif. (lat. $36^{\circ} 4 \mathrm{l}^{\prime} \mathrm{N}$, long. $121^{\circ} 38^{\prime} \mathrm{W}$ ), of the Monterey County lettuce-producing area. In contrast, from mid May to end of July, civil twilight extends the day to 24 h (U.S. Naval Observatory, 2006) in interior Alaska (lat. 64 $49^{\circ} \mathrm{N}$ ).

High tunnels may be appropriate for improving and extending lettuce field production at high latitudes where frost, delayed snowmelt, and other seasonable conditions may curtail an already short growing season. In Saskatchewan, Canada (lat. $52^{\circ} 10^{\prime} \mathrm{N}$, long. $106^{\circ} 4 \mathrm{l}^{\prime} \mathrm{W}$ ), the romaine lettuce cultivars Conquistador and Green Forest produced earlier and larger yields in a high tunnel environment (Waterer et al., 2005). The objective of our study was to evaluate yield and size differentials in a northern location for romaine and leaf lettuce planted sequentially throughout the season in a high tunnel and the field.

\section{Materials and methods}

This study was conducted during Summer 2005 at the University of Alaska Fairbanks Experiment Farm (lat. $64^{\circ} 49^{\prime} \mathrm{N}$, long. $147^{\circ} 52^{\prime} \mathrm{W}$, elevation $144 \mathrm{~m}$ ). From April through September, precipitation averages 20.7 $\mathrm{cm}$ and there is an average of 94 frostfree days (Benz et al., 2005). The soil type at the growing site was a loamy, mixed, nonacid Pergelic Cryaquepts in the Tanana series (Furbush et al., 1980).

A romaine-type lettuce, 'Parris Island Cos MI', and a leaflettuce, 'Two Star MI', were selected for the study. Pelleted seeds (Osborne International Seed Co., Mount Vernon, Wash.) were propagated in 200-cell plug flats using Premier Pro-Mix BX (Premier Horticulture, Premier Brands, Inc., Red Hill, $\mathrm{Pa}$.) for 4 weeks prior to transplant to the field. A ClearSpan, two-bay high tunnel (ClearSpan, Dyersville, Iowa) with dimensions of $15.8 \mathrm{~m}$ wide, 3.7 $\mathrm{m}$ high, and $14.6 \mathrm{~m}$ long and covered with a single layer of 6-mil polyethylene plastic (Tyco Tufflite IV ultraviolet blocked; Tyco Plastics and Adhesives Division of Tyco, Inc., Monroe, La.) was used. A drip-tape irrigation system (T-tape; T-Systems International, San Diego) was used to maintain soil moisture readings above $-30 \mathrm{kPa}$ using a tensiometer positioned at $10 \mathrm{~cm}$ depth in the plots. Emitters were spaced 20 $\mathrm{cm}$ apart with a flow rate of $250 \mathrm{~L} \cdot \mathrm{h}^{-1}$ per $100 \mathrm{~m}$. The $\mathrm{pH}$ of the irrigation water was 7.4 and electric conductivity was $0.62 \mathrm{mmho} / \mathrm{cm}$. Each plot was fertilized prior to planting at a rate of $20 \mathrm{~N}-4.4 \mathrm{P}-8.3 \mathrm{~K}$ using $540 \mathrm{~kg} \cdot \mathrm{ha}^{-1}$ (urea, triple phosphate, and potassium sulfate) based on recommendations for Oregon-grown lettuce (Hemphill, 2004). Temperatures were recorded at $10 \mathrm{~min}$ intervals $15 \mathrm{~cm}$ below and 1 $m$ aboveground inside and outside the high tunnel using a Watchdog Data Logger temperature sensor, 400/200 Series, (Spectrum Technologies, Inc, Plainfield, Ill.). Temperatures for each calendar day were averaged and reported as monthly averages (Table 1). Side and end walls were manually opened and closed to provide ventilation during warm days.

A randomized complete-block design was used. The main plot factor was environment (high tunnel or open field) and subplot factors were planting date and cultivar. Eighteen, uniform lettuce transplants were manually transplanted to $60 \times 120$-cm plots $\left(0.72 \mathrm{~m}^{2}\right)$ approximately $25 \mathrm{~cm}$ apart in a $6 \times 3$ grid. Ten planting dates were incrementally spaced 1 week apart from 25 May to 10 Aug. (Table 2). The first lettuce was harvested on 4 July and the final harvest was $28 \mathrm{Sept}$. The earliest planting (18 May) was destroyed by high winds along with a single bay high tunnel. 'Two Star' planted on 1, 8, 15, and 22 June was rendered damaged beyond marketable quality by rodents. However, the final five plantings (13, 20, and 27 July; 3 and 10 Aug.) of 'Two Star', achieved maturity.

Periodic height measurements were made of five randomly selected plants from the 25 May, 15 June, 13 and 27 July, and 10 Aug. plantings. Entire plots were harvested approximately 6 weeks after planting when more than $50 \%$ of the plants had developed firm mature heads or were bolting 
in either location. Head weight and height were recorded and position in the plot noted. Several leaves of variable age were selected from four randomly chosen heads in the 21 June and 5 July plantings for soluble solid concentration (SSC) using a Digital Pocket Refractometer (Spectrum Technologies, Inc.). Four heads were also oven dried at $68^{\circ} \mathrm{C}$ and weighed after 3 d. PROC GLM (SAS Institute Inc., Cary, N.C.) repeated measures analysis was used for growth rates using log transformed height while ANOVA was used for yield variables.

\section{Results and discussion}

Air and soil temperature differentials between the tunnel and the field varied widely throughout the season (Fig. 1). With the ends of the tunnel left completely open in June, air averaged $1.2^{\circ} \mathrm{C}$ and soil $0.2^{\circ} \mathrm{C}$ higher than the field. In contrast, even late in the season, maximum daily temperature would increase rapidly in a closed tunnel under sunny conditions. Attention to ventilation practices was therefore essential as air averaged $2.5{ }^{\circ} \mathrm{C}$ and soil $2.6{ }^{\circ} \mathrm{C}$ higher than the field in an unventilated tunnel on 25 Sept.

The high tunnel offered some protection, when completely closed, during the first severe frost of $2 \mathrm{Sept}$. (Fig. 2) as reflected in an average 5.8 ${ }^{\circ} \mathrm{C}$ higher air and $3.5^{\circ} \mathrm{C}$ higher soil temperature. The soil remained above freezing while air dropped to $-1.7^{\circ} \mathrm{C}$ in the tunnel and $-4.6^{\circ} \mathrm{C}$ in the field. Still, 'Parris Island Cos' and 'Two Star' were not damaged by frost in the high tunnel or in the field on 2 Sept.

Planting date affected yield and other measured variables for both cultivars (Table 3). Although overall yield did not differ in the two environments for 'Two Star', there were significant interactions between environment and time of planting. The first planting on 25 May produced a larger yield than subsequent plantings with average head weight of $374 \pm 36 \mathrm{~g}$ in the field and $421 \pm 12 \mathrm{~g}$ in the tunnel (Fig. 3).

Growth and development of 'Two Star' planted on 13 July and 3 Aug. varied between environments. For 'Two Star' planted on 13 July, the field produced more $(P<0.001)$ at $202 \pm$ $21 \mathrm{~g} /$ head than the $135 \pm 29 \mathrm{~g} /$ head in the tunnel. Head weight averaged $195 \pm 12 \mathrm{~g}$ in the tunnel and $99 \pm 8 \mathrm{~g}$ in the field for the 3 Aug. planting.

The rate of height increase was

Table 1. Minimum, average, and maximum temperatures in a high tunnel and the field used to grow leaf lettuce 'Two Star' and romaine lettuce 'Parris Island Cos'. Temperatures were recorded $1 \mathrm{~m}(3.3 \mathrm{ft})$ aboveground and at $15-\mathrm{cm}(5.9$ inches) soil depth. Temperatures were recorded at 10 -min intervals and averaged.

\begin{tabular}{|c|c|c|c|c|c|c|}
\hline \multirow[b]{2}{*}{ Month } & \multicolumn{2}{|c|}{ Minimum } & \multicolumn{2}{|c|}{ Average } & \multicolumn{2}{|c|}{ Maximum } \\
\hline & Tunnel & Field & Tunnel & Field & Tunnel & Field \\
\hline \multicolumn{7}{|c|}{ Aiv temp $\left({ }^{\circ} \mathrm{C}\right)^{z}$} \\
\hline Late May & $8.3 \pm 2.6$ & $9.6 \pm 2.9$ & $19.0 \pm 2.4$ & $18.5 \pm 3.8$ & $31.6 \pm 1.7$ & $29.3 \pm 4.0$ \\
\hline June & $9.1 \pm 2.0$ & $8.4 \pm 2.1$ & $18.7 \pm 4.0$ & $17.5 \pm 3.8$ & $30.8 \pm 6.6$ & $28.6 \pm 6.2$ \\
\hline July & $9.9 \pm 3.0$ & $9.4 \pm 2.9$ & $19.3 \pm 2.5$ & $18.1 \pm 2.1$ & $31.6 \pm 4.2$ & $30.1 \pm 3.5$ \\
\hline August & $7.5 \pm 3.2$ & $6.7 \pm 3.6$ & $16.9 \pm 3.8$ & $15.0 \pm 4.0$ & $29.5 \pm 5.8$ & $27.8 \pm 6.6$ \\
\hline September & $4.0 \pm 2.6$ & $2.5 \pm 3.0$ & $10.6 \pm 2.8$ & $8.1 \pm 3.0$ & $22.7 \pm 7.2$ & $17.6 \pm 6.7$ \\
\hline May-Sept. & $7.8 \pm 2.7$ & $7.3 \pm 2.9$ & $16.9 \pm 3.1$ & $15.4 \pm 3.3$ & $29.2 \pm 5.1$ & $26.7 \pm 5.4$ \\
\hline \multicolumn{7}{|c|}{ Soil temp $\left({ }^{\circ} \mathrm{C}\right)$} \\
\hline Late May & $12.7 \pm 0.9$ & $13.4 \pm 1.2$ & $14.8 \pm 0.9$ & $15.7 \pm 1.1$ & $18.5 \pm 4.1$ & $19.0 \pm 2.8$ \\
\hline June & $15.0 \pm 1.8$ & $14.7 \pm 2.1$ & $17.2 \pm 2.0$ & $17.0 \pm 2.2$ & $20.2 \pm 3.4$ & $20.2 \pm 3.7$ \\
\hline July & $17.5 \pm 1.4$ & $16.5 \pm 1.1$ & $19.6 \pm 0.9$ & $18.6 \pm 1.0$ & $21.3 \pm 1.2$ & $20.8 \pm 1.4$ \\
\hline August & $15.3 \pm 1.8$ & $14.4 \pm 2.2$ & $16.9 \pm 2.1$ & $16.1 \pm 2.6$ & $18.6 \pm 2.3$ & $18.0 \pm 3.0$ \\
\hline September & $10.5 \pm 2.3$ & $7.9 \pm 1.9$ & $11.8 \pm 1.7$ & $9.2 \pm 1.8$ & $13.2 \pm 1.9$ & $10.7 \pm 1.8$ \\
\hline May-Sept. & $14.2 \pm 1.6$ & $13.4 \pm 1.7$ & $16.1 \pm 1.5$ & $15.3 \pm 1.7$ & $18.4 \pm 2.6$ & $17.7 \pm 2.6$ \\
\hline
\end{tabular}

Table 2. Average air and soil temperatures for each cropping period of leaf lettuce 'Two Star' and romaine lettuce 'Parris Island Cos' in a high tunnel and the field. Temperatures were recorded $1 \mathrm{~m}(3.3 \mathrm{ft})$ aboveground and at $15 \mathrm{~cm}(5.9$ inches) soil depth. Temperatures were recorded at $10-$ min intervals and averaged.

\begin{tabular}{|c|c|c|c|c|c|c|}
\hline \multirow[b]{2}{*}{ Planting } & \multirow[b]{2}{*}{ Harvest } & \multirow[b]{2}{*}{ Crop days } & \multicolumn{2}{|c|}{$\operatorname{Air}\left({ }^{\circ} \mathbf{C}\right)^{\mathrm{z}}$} & \multicolumn{2}{|c|}{ Soil $\left({ }^{\circ} \mathrm{C}\right)$} \\
\hline & & & Tunnel & Field & Tunnel & Field \\
\hline 25 May & 4 July & 40 & $18.8 \pm 3.6$ & $17.6 \pm 3.6$ & $17.0 \pm 2.2$ & $16.9 \pm 2.0$ \\
\hline 1 June & 11 July & 40 & $18.7 \pm 3.4$ & $17.5 \pm 3.3$ & $17.9 \pm 2.1$ & $17.3 \pm 2.0$ \\
\hline 8 June & 18 July & 40 & $19.6 \pm 3.0$ & $18.3 \pm 2.7$ & $18.8 \pm 1.7$ & $18.1 \pm 1.3$ \\
\hline 15 June & 25 July & 40 & $19.1 \pm 2.8$ & $17.9 \pm 2.5$ & $18.9 \pm 1.7$ & $18.3 \pm 1.3$ \\
\hline 22 June & 1 Aug. & 40 & $19.1 \pm 2.7$ & $17.9 \pm 2.5$ & $19.1 \pm 1.4$ & $18.3 \pm 1.1$ \\
\hline 13 July & 19 Aug. & 37 & $19.3 \pm 3.1$ & $17.8 \pm 2.8$ & $18.9 \pm 1.4$ & $18.3 \pm 1.4$ \\
\hline 20 July & 30 Aug. & 41 & $17.6 \pm 3.6$ & $15.9 \pm 3.8$ & $17.6 \pm 2.1$ & $16.9 \pm 2.4$ \\
\hline 27 July & 2 Sept. & 37 & $16.7 \pm 3.8$ & $14.7 \pm 4.3$ & $16.9 \pm 2.2$ & $16.1 \pm 2.9$ \\
\hline 3 Aug. & 16 Sept. & 44 & $15.2 \pm 4.0$ & $13.2 \pm 4.4$ & $15.5 \pm 2.7$ & $14.1 \pm 3.6$ \\
\hline 10 Aug. & 28 Sept. & 49 & $13.2 \pm 4.2$ & $11.1 \pm 4.7$ & $14.0 \pm 2.9$ & $12.2 \pm 3.9$ \\
\hline
\end{tabular}

${ }^{2}\left(1.8 \times{ }^{\circ} \mathrm{C}\right)+32={ }^{\circ} \mathrm{F}$.

only different $(P<0.01)$ for the 13 July 'Two Star' planting (data not shown). The daily elongation rate in the field was $5.5 \%$ and $3.7 \%$ in the tunnel. Percent dry mass was greater $(P<0.05)$ for lettuce growing in the field at $8.5 \%$ compared to $5.7 \%$ in the tunnel (data not shown). Sugar analysis for the 20 July planting suggested 5.3\% SSC for tunnel-grown and $6.5 \%$ for field-grown lettuce (data not shown).

Environment significantly affected yield of 'Parris Island Cos' (Table 3 ) for three consecutive plantings in June (Fig. 3). Head weight for the 1 June planting was $457 \pm 60 \mathrm{~g}$ in the field and $354 \pm 46 \mathrm{~g}$ in the tunnel $(P$ $<0.05)$. Similarly, the field produced larger heads $(476 \pm 65 \mathrm{~g})$ than the tunnel $(331 \pm 52 \mathrm{~g})$ for the 8 June planting. The 15 June planting had similar results at $478 \pm 25 \mathrm{~g} / \mathrm{head}$ and slightly smaller lettuce $(312 \pm 14 \mathrm{~g})$ in the tunnel.

Growth of 'Parris Island Cos' based on height was faster in the tunnel for crops planted on 13 July $(P<$ $0.05)$ and 10 Aug. $(P<0.001)$ (data not shown). Similar to 'Two Star', the dry weight proportion was higher in the open field $(P<0.01)$ at $6.3 \%$ than the $5.2 \%$ recorded in the tunnel for the 20 July and 3 Aug. plantings (data not shown). On the other hand, 'Parris Island Cos' had higher SSC values in the tunnel $(5.4 \%)$ than the field $(4.8 \%$, data not shown).

In general, lettuce planted prior to July produced higher yields. The lower productivity for lettuce planted 
mid-season may be due to higher than optimal temperatures during planting and establishment. However, poor transplant quality may also have contributed to the overall reduced growth. All lettuce seedlings were grown for 4 weeks in a greenhouse under natural irradiance and long days prior to field planting. Although attempts were made to maintain uniform propagation conditions, greenhouse temperature increased with the outside environment and daylengths up to $21 \mathrm{~h} 49 \mathrm{~min}$ between sunrise and sunset on 21 June (U.S. Naval Observatory, 2006). High irradiance, elevated temperatures and extended daylengths have previously been found to predispose lettuce transplants to bolting after planting (Dennis and Dulforce, 1974; Klapwijk, 1979). Direct seeding should be evaluated as an alternative to transplanting during the warmest period of the season. In addition to potential productivity improvements, direct seeding eliminates the need for an automated greenhouse and reduces labor for producing and planting lettuce transplants.

Growth rate based on height was not a useful indicator of yield potential for either 'Two Star' or 'Parris Island Cos'. The 13 July and 10 Aug. plantings of 'Parris Island Cos' increased faster in the tunnel probably due to excessive stem elongation rather than leaf expansion since yield differences were nonsignificant. No difference in elongation rate was observed between locations for 'Two Star' planted 3 Aug. although the tunnel harvest was larger. On the other hand, a more rapid height increase in field-grown 'Two Star' planted 13 July did result in higher yield. Field-grown lettuce also had higher dry weight proportion in this study. A higher SSC suggested 'Two Star' lettuce grown in open fields to be more palatable. Although 'Parris Island Cos' proportionally also had more dry weight, SSC did not increase in the field. Further studies are necessary to determine potential variations in dry weight, nutritional and taste characteristics between field and high tunnel-grown lettuce.

Similar to 'Two Star', the productivity of 'Parris Island Cos' decreased as the season progressed through September (Fig. 3) in both environments. Additional time was required for the 10 Aug. planted lettuce to mature and harvest was delayed more
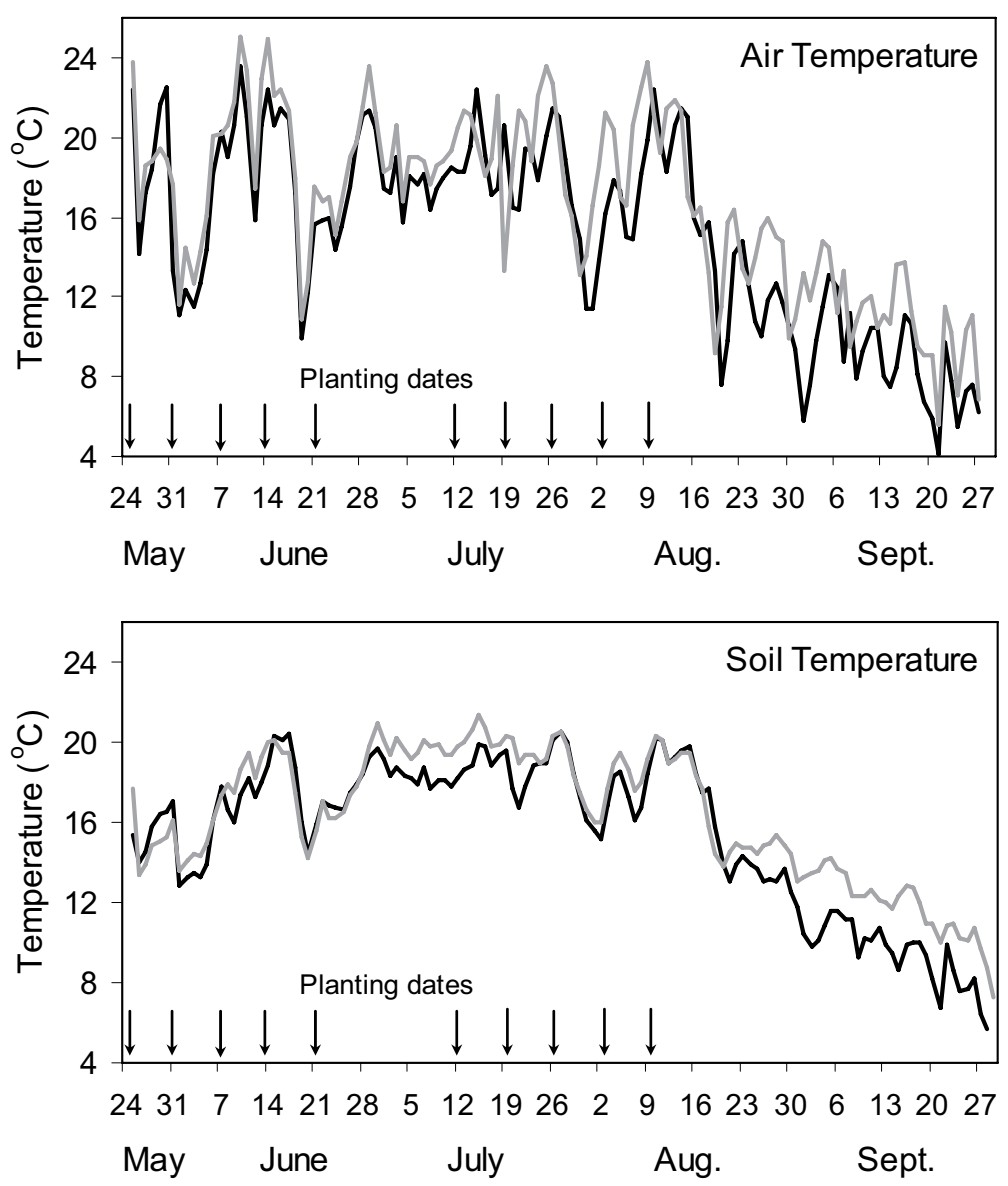

Fig. 1. Average daily air [ $1 \mathrm{~m}(3.3 \mathrm{ft}$.$) aboveground ]$ and soil $[15 \mathrm{~cm}(5.9$ inches) depth] temperatures in a high tunnel (grey) and the open field (black) used to grow leaf lettuce 'Two Star' and romaine lettuce 'Parris Island Cos'. The arrows indicate the ten planting dates. 'Two Star' planted on 1, 8, 15, and 22 June did not mature due to severe rodent damage; $\left(1.8 \times{ }^{\circ} \mathrm{C}\right)+32={ }^{\circ} \mathrm{F}$.

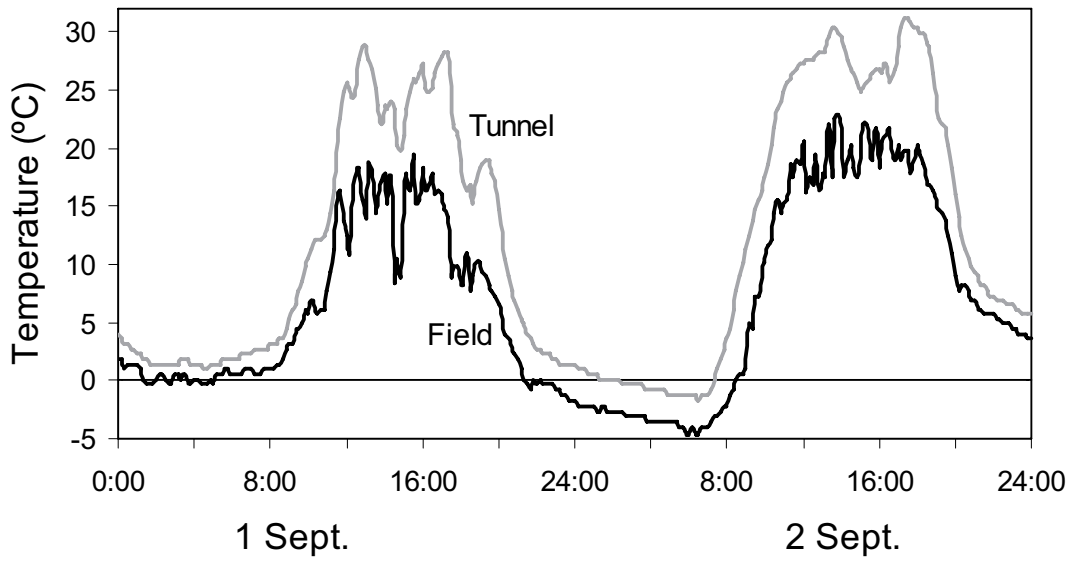

Fig. 2. Air temperature recorded every $10 \mathrm{~min}, 1 \mathrm{~m}(3.3 \mathrm{ft})$ aboveground, in a high tunnel and open field used to grow leaf lettuce 'Two Star' and romaine lettuce 'Parris Island Cos'. Measurements were made on 1 and 2 Sept. 2005; (1.8 × $\left.{ }^{\circ} \mathrm{C}\right)+32={ }^{\circ} \mathrm{F}$. 
Table 3. ANOVA for head weight and height of leaf lettuce 'Two Star' and romaine lettuce 'Parris Island Cos'. The lettuce was grown in a high tunnel or the field (environment). Six sequential plantings of 'Two Star' and 10 plantings of 'Parris Island Cos' reached maturity.

\begin{tabular}{|c|c|c|c|c|c|}
\hline & \multirow[b]{2}{*}{ df } & \multicolumn{2}{|c|}{ Weight $(g)^{z}$} & \multicolumn{2}{|c|}{ Height $(\mathrm{cm})^{\mathrm{y}}$} \\
\hline & & $\mathbf{F}$ & $P$ & $\mathrm{~F}$ & $P$ \\
\hline \multicolumn{6}{|c|}{ Two Star } \\
\hline Environment & 1 & 2.43 & 0.1207 & 0.02 & 0.8959 \\
\hline Planting & 5 & 73.61 & $<0.0001$ & 4.14 & 0.0013 \\
\hline Environment $\times$ planting & 5 & 4.40 & 0.0008 & 1.74 & 0.1270 \\
\hline \multicolumn{6}{|c|}{ Parris Island Cos } \\
\hline Environment & 1 & 5.15 & 0.0239 & 2.63 & 0.1055 \\
\hline Planting & 9 & 32.85 & $<0.0001$ & 6.66 & $<0.0001$ \\
\hline Environment $\times$ planting & 9 & 2.97 & 0.0021 & 3.41 & 0.0005 \\
\hline
\end{tabular}

${ }^{2} \mathrm{~g}=0.0353 \mathrm{oz}$.

${ }^{\mathrm{y}} 1 \mathrm{~cm}=0.3937$ inch.
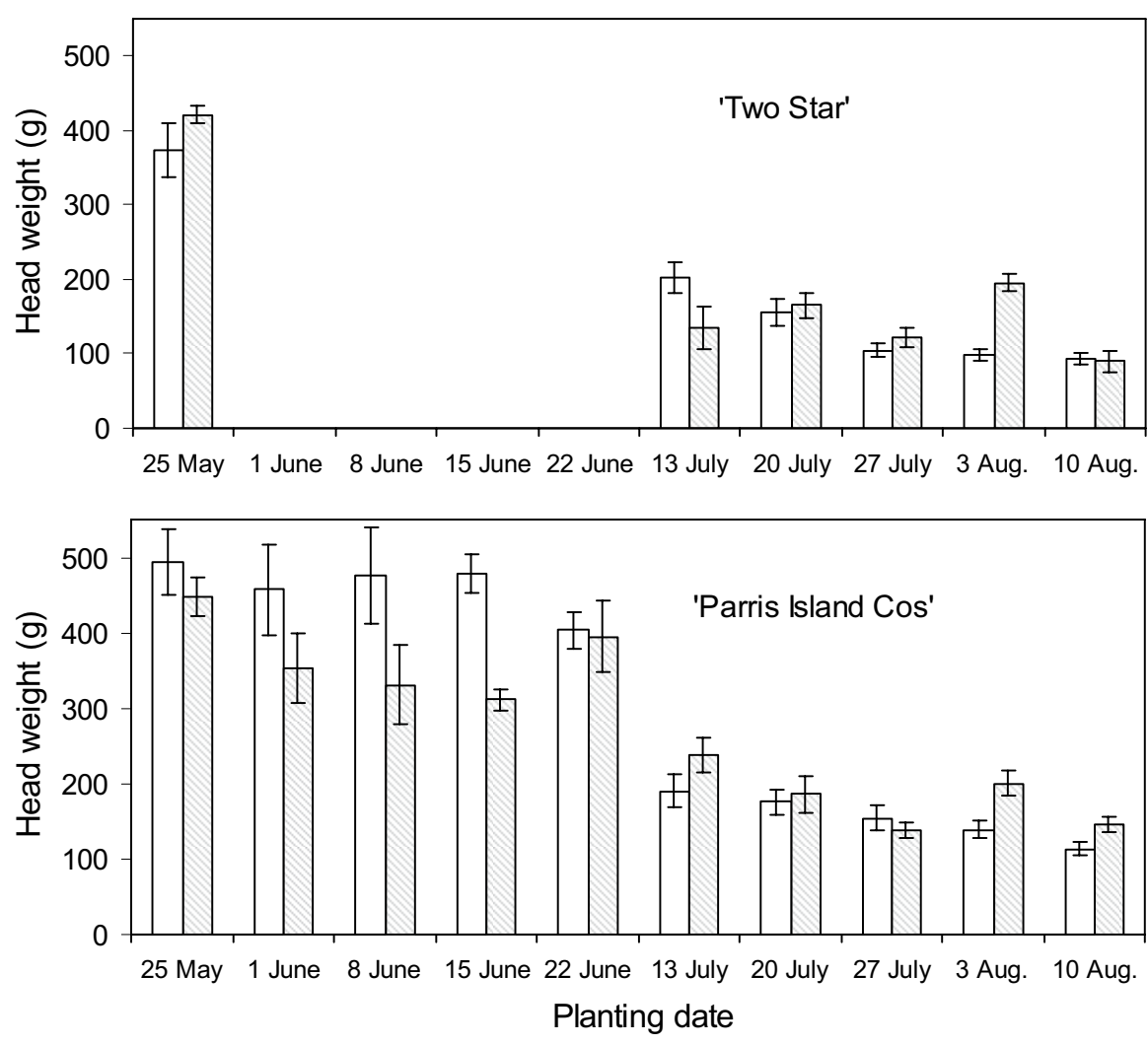

Fig. 3. Average lettuce head weight (grams) with standard error bars, for each planting date of leaf lettuce 'Two Star' and romaine lettuce 'Parris Island Cos'. High tunnel lettuce is represented by cross-hatched bars while field-grown lettuce is represented by white bars; $1 \mathrm{~g}=0.0353 \mathrm{oz}$.

than a week compared to most other plantings (Table 2). Decreasing air and soil temperatures are expected to slow growth, although other factors may influence late season lettuce production. Lettuce harvested on 16 and 28 Sept. was planted when temperatures were high on 3 and 10 Aug. The initial establishment and development at high temperatures may have affected the lettuce. For instance, the leaf lettuce 'Salad Bowl' was reported bolt resistant in local field trials while 'Parris Island Cos' was noted for high yield and quality but also increased tendency to bolt (Hébert and Matheke, 2004). Cultivars with the phenotypic variability to exploit improved growing conditions should be identified (Wells and Loy, 1985). Zhao et al. (2003) tested 30 lettuce cultivars in Kansas and found romaine, oak leaf and butterhead types to be less likely to bolt than leaf lettuce in high tunnel environments. In our trials, we found the opposite: 'Two Star' seemed less prone to bolt compared to 'Parris Island Cos' in the high tunnel which may have been due to naturally prolonged days compared with Kansas.

The most cost effective production time for local markets is expected early or late in the season when supply usually is more limited. The 3 Aug. planting of 'Two Star' suggested high tunnels would improve yields later in the growing season, but the first planting of 25 May did not show any advantage of a high tunnel environment for yield and rate of growth (Fig. 3 ). The option of temporarily heating the high tunnel during forecasted, mild frosts would further improve end of season crop dependability.

The historical average July temperature for Fairbanks Experiment Farm is $16.1{ }^{\circ} \mathrm{C}$ (Benz et al., 2005). July 2005 was recorded at a $2{ }^{\circ} \mathrm{C}$ higher average of $18.1{ }^{\circ} \mathrm{C}$ (Table $\mathrm{l}$ ). A colder, less optimal season than 2005 may further favor a high tunnel environment over the field for lettuce productivity. Even if lettuce yields were not significantly greater, the added protection from precipitation, wind, and to some extent frost should also be valued. Lettuce harvested in the high tunnel was clean while field-grown lettuce required labor intense washing especially following heavy precipitation, before marketing.

Higher value, specialty crops with marginal hardiness are more likely to benefit from a seasonal, high tunnel growing area and should be prioritized to offset the additional construction and management costs of the structure. High value salad crops such as baby salad or specialty greens may also be more sensible choices for mid-season high tunnel production than leaf or romaine lettuce. 


\section{Literature cited}

Alaska Climate Research Center. 2006. Monthly time series data, Fairbanks, AK. 19 July 2006. <http://climate.gi.alaska. edu/Climate/Location/TimeSeries/Fairbanks.html>.

Benz, S., G. Lucero, and C. Messer. 2005. Alaska agricultural statistics 2005. 11 July 2006. <http://www.nass.usda. gov/Statistics_by_State/Alaska/Publications/Annual_Statistical_Bulletin/annual2005.pdf>.

Bierhuizen, J.F., J.L. Ebbens, and N.C.A. Koomen. 1973. Effects of temperature and radiation on lettuce growing. Neth. J. Agr. Sci. 21:110-116.

Boxall, M.I. 1971. Some effects of soil warming on plant growth. Acta Hort. 22:57-65.

Challa, H. 1990. Crop growth models for greenhouse climate control, p. 125-145. In: R. Rabbinge, J. Goudriaan, H. Van Keulen, F.W.T. Penning de Vries, and H.H. Van Laar (eds.). Theoretical production ecology: Reflections and perspectives. Simulation Monogr. 34. Wageningen Press, Wageningen, The Netherlands.

Dennis, D.J. and W.M. Dullforce. 1974. Analysis of the subsequent growth and development of winter glasshouse lettuce in response to short periods in growth chambers during propagation. Acta Hort. 39:197-218.

Furbush, C.E., B.E. Koepke, and D.B. Schoephorster. 1980. Soil survey of Totchaket area, Alaska. 11 July 2006. <http:// soils.usda.gov/survey/online_surveys / alaska/totchaket/totchaket.pdf>.

Glenn, E.P. 1984. Seasonal effects of radiation and temperature on growth of greenhouse lettuce in a high insolation desert environment. Scientia Hort. 22:9-21.

Hancock, J. and D. Simpson. 1995. Methods of extending the strawberry season in Europe. HortTechnology 5:286-291.
Hébert, M. and Matheke, G. 2004. Vegetable and fruit varieties for interior Alaska. Univ. of Alaska Fairbanks, Coop. Ext. Serv. Publ. HGA-00030. 11 July 2006. <http://www.uaf.edu/ces/publications/ freepubs/HGA-00030.pdf>.

Hemphill, D. 2004. Lettuce Lactuca sativa. 11 July 2006. <http://oregonstate. edu/Dept/NWREC/lettuce.html>.

Hodges, L. and J.R. Brandle. 1996. Windbreaks: An important component in a plasticulture system. HortTechnology 6:177-181.

Jackson, L., K. Mayberry, F. Laemmlen, S. Koike, K. Schulbach, and W. Chaney. 1996. Leaflettuce production in California. Div. of Agr. and Natural Resources Publ. 7216. Univ. of California, Davis. 11 July 2006. <http://anrcatalog.ucdavis.edu/ pdf/7216.pdf>.

Kadir, S., E. Carey., and S. Ennahli. 2006. Influence of high tunnel and field conditions on strawberry growth and development. HortScience 41:329-335.

Klapwijk, D. 1979. Seasonal effects on the cropping cycle of lettuce in glasshouses during the winter. Scientia Hort. 11:371-377.

Kurtz, E.A. 2001. Crop profile of leaf lettuce in California. 11 July 2006. <http:// www.ipmcenters.org/cropprofiles/docs/ calettuce-leaf.html>.

Lamont, W.J., M.D. Orzolek, E.J. Holcomb, K. Demchak, E. Burkhart, L. White, and B. Dye. 2003. Production system for horticultural crops grown in the Penn State high tunnel. HortTechnology 13:358-362.

Nothmann, J. 1977a. Morphogenetic effects of seasonal conditions on head development of cos lettuce (Lactuca sativacv. Romana) growing in a subtropical climate. J. Hort. Sci. 52:155-162.
Nothmann, J. 1977b. Effects of soil temperature on head development of cos lettuce. Scientia Hort. 7:97-105.

Pearson, S., T.R. Wheeler, P. Hadley, and A.E. Wheldon. 1997. A validated model to predict the effects of environment on the growth of lettuce (Lactuca sativa L.): Implications for climate change. J. Hort. Sci. 27(4):503-517.

Ryder, E.J. 1979. Leafy salad vegetables. Avi, Westport, Conn.

U.S. Naval Observatory. 2006. Sunrise/ sunset table for one year. 11 July 2006. <http://aa.usno.navy.mil/>.

Waterer, D. 2003. Yields and economics of high tunnels for production of warmseason vegetable crops. HortTechnology 13:339-343.

Waterer, D., J. Bantle, andW.Hrycan. 2005. Vegetable cultivars and cultural trials 2005. 11 July 2006. <http://www.usask.ca/ agriculture/plantsci/vegetable/2005/ $2005 \mathrm{veg} / 2005 \mathrm{resources} / 2005 \mathrm{VCCT}$. pdf $>$.

Wells, O.S. and J.B. Loy. 1985. Intensive vegetable production with row covers. HortScience 20:822-826.

Wells, O.S. and J.B. Loy. 1993. Rowcovers and high tunnels enhance crop production in the northeastern United States. HortTechnology 3:92-95.

Wien, H.C. 1997. Lettuce, p. 479-510. In: H.C. Wien (ed.). Vegetable crop physiology. CABI Publ., Cambridge, Mass.

Zhao, X., E.E. Carey, and M. Hall. 2003. Influence of protected environment and fertilizer source on growth and quality of lettuce and leafy greens during summer production in Kansas. HortScience 38:749 (Abstr.). 